\title{
La modernidad o el drama de la identidad: máscara, lenguaje y memoria en Persona, de Ingmar Bergman
}

\author{
Modernity or the drama of identity: mask, language \\ and memory in Persona, by Ingmar Bergman
}

DAVID VÁZQUEZ COUTO*

\begin{abstract}
Resumen: Persona (1966), de Ingmar Bergman, especula sobre la ausencia de una esencia, vana promesa de una idea velada tras el individuo convertido en imagen de sí mismo. Discernir el ser del parecer y el pensar del decir entre los reflejos que se pierden por el tenebroso terreno del lenguaje despierta la conciencia del abismo comunicativo que condena al hombre a una soledad perpetua. El hombre, actor y espectador de la vida, construye el relato de su existencia siguiendo las frágiles huellas de la memoria. Persona es el conflicto entre el rostro y la máscara; el drama moderno de la identidad encerrada en la imagen que disimula la verdad de la nada.

Palabras clave: Ingmar Bergman, Persona, identidad, rostro, máscara, cine.
\end{abstract}

\begin{abstract}
Persona (1966), by Ingmar Bergman, speculates about the absence of an essence, vain promise of a veiled idea behind the individual converted into an image of himself. To discern the being from the appearing and the thinking from the saying between reflections that are lost through the dark terrain of language awakens the consciousness of the communicative abyss that condemns man to a perpetual solitude. The man, actor and spectator of life, constructs the story of his existence following the fragile traces of memory. Persona is the conflict between the face and the mask; the modern drama of identity locked in the image that conceals dissimulates the truth of nothingness.
\end{abstract}

Keywords: Ingmar Bergman, Persona, identity, face, mask, cinema.

«¿Es posible que no seamos siempre la misma persona?» Alma en Persona (Ingmar Bergman, 1966)

Fecha de recepción: 13/06/2016. Fecha de aceptación: 27/07/2016.

* Doctorando del Departamento de Filosofía, Lógica y Estética de la Universidad de Salamanca (davidcouto@

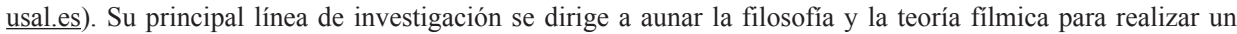
análisis estético de la obra de Ingmar Bergman. En 2016 ha publicado artículos como «Apariencias de la variación: fisonomía y alegoría en el retrato cinematográfico de Ingmar Bergman», FOTOCINEMA. Revista Cientifica de Cine y Fotografia, n 12, pp. 131-154; e «Images of social control. Fear and shock in the viewer of a world under threat», Re-visiones, $\mathrm{n}^{\circ} 5$. 


\section{La modernidad o el drama de la identidad}

Persona, una de las obras más complejas de Ingmar Bergman, se estrena ante el público sueco en 1966 provocando una profunda impresión en la memoria de la modernidad cinematográfica. El film se refiere a la inmaculada contemplación que permite desentramar la escenografía del mundo a través de la imagen cinematográfica; proceso por el cual la cámara se convierte en un instrumento mágico de disección fenomenológica que busca la distinción objetiva entre la realidad y la ficción mediante la experiencia subjetiva de la imagen.

Kinematograf, el título original de la película (finalmente descartado por motivos comerciales), ofrece la primera pista sobre las intenciones de su autor (Björkman, Manns \& Sima, 1973, 201). Cinematografía y persona juegan de manera perversa con la ocultación y la mostración, con la imagen de un paisaje de distancias y profundidades desdoblado en el interior del sujeto. Eugenio Trías afirma que «en la subjetividad se introduce la escisión entre el ego y el mundo objetivo» $(1974,79)$, lo que supone la «condición limítrofe» del hombre: la imposibilidad de unión con el mundo debido al olvido de los orígenes (2000, 510). El viaje épico en busca de la identidad es lo que descubre esta «peculiar situación de encrucijada» en el hombre (Trías, 1974, 104); un callejón sin salida donde el narrador del drama existencial sigue las huellas de un tiempo pasado en busca de su naturaleza primigenia. Bergman intenta desesperadamente trascender la imagen con la religiosidad que exige cualquier tipo de idealismo, pero se encuentra con el reflejo aflictivo de un desconocido, el otro, que niega cualquier respuesta romántica, cualquier idea invisible que satisfaga la necesidad de creer que hay algo más detrás de lo visible.

Si Trías sugiere, a partir de su interpretación de El nacimiento de la tragedia de Nietzsche, que Eurípides consolida el drama moderno que «comienza a ser autoconsciente» y en el que «no hay correspondencia entre el hablar y el ser ni entre el pensar y el ser. No hay, pues, posibilidad de verdad» (1974, 98-99), Ingmar Bergman da un vuelco a la modernidad cinematográfica al filmar el mismo conflicto de aquel drama moderno de la época clásica. En Persona la validez y la continuidad del lenguaje quedan en entredicho cuando la palabra hace surgir la máscara como imagen proyectada por uno mismo. Son los límites del ser y el parecer los que crean la tensión de individualidad y universalidad en el hombre moderno -melancólico de la identidad perdida en la profundidad de la máscara- que busca la verdad de un yo disfrazado de otros muchos yoes; un yo esquivo y fugitivo que permanece oculto en las sombras de la conciencia. José Luis Molinuevo, al referirse a la composición variable de «la imagen del rostro jánico de Alma-Elisabeth» proyectada sobre la pantalla, explica que este plano representa a las «identidades borrosas» de la modernidad: «Es un paso de las identidades simples a las compuestas. Las identidades borrosas son el efecto de las personalidades múltiples» (2010, 217). Otros rostros son mi rostro, por lo que el retorno del hombre moderno a las ruinas de la memoria será su condena nostálgica a lo desconocido. Y si ya Locke afirmaba que para ser persona es necesaria una conciencia de sí mismo, Persona logra ser objeto fílmico consciente de su filmicidad. Lo mismo sucede con sus personajes -Elisabet Vogler (Liv Ullmann) y Alma (Bibi Andersson)-, pues sufren la angustia de contemplar el horror del más absoluto vacío al verse atrapados en el interior del film, es decir, en la duración de la proyección de la imagen sobre la pantalla. Es por esto que Laura Hubner afirma que «el motivo de la máscara culmina en el primer plano compuesto de Alma y Elisabet [...] aludiendo a la máscara de 
la cinematografía» $(2007,71)$. No hay ser sino representación. Y el mito de la caverna es tan sólo eso, un mito. Ambos rostros se funden para representar la gran farsa de la tradición platónica, cuya idea tras la imagen da lugar a la suposición de una verdad cognoscible tras el rostro. Persona se convierte entonces en una inflexión de la modernidad cinematográfica al proponer «la descomposición no sólo de un modelo narrativo, sino también de una cierta concepción figurativa de la imagen» (Losilla, 2010,72), ya que el planteamiento de la nueva forma que envuelve al film se dirige a exponer la auténtica identidad del hombre, diluida entre el rostro y la máscara, en paralelo metafórico con la imagen fílmica. En este sentido, Persona supone la culminación de la modernidad cinematográfica iniciada con el neorrealismo tras la segunda gran guerra, aquella a la que le pertenece la «imagen-tiempo» deleuziana. El film de Bergman da una vuelta de tuerca a la actitud «documentalizante»" impulsada por la corriente crítica de los Cahiers du Cinéma durante los años sesenta. Si bien los autores franceses de la Nouvelle vague consideraban que toda película que se precie debía tratar sobre su propio rodaje, sobre sí misma, esto no dejaba de ser un ejercicio de rebeldía metafílmica ante los imperativos lingüísticos y los significantes del cine clásico. Se trataba, a grandes rasgos, de concienciar al espectador del inmenso poder ficcional del cine -la ensoñación fílmica del público se veía interrumpida con la inclusión de los focos y las cámaras del set de rodaje en el plano, miradas a cámara y otros recursos formales de distanciamiento-. Pues bien, Ingmar Bergman lleva hasta el límite esta idea del cine que se mira al espejo; sin embargo, al mostrar las vísceras del film desde su interior, confunde los límites de la realidad mezclando lo filmado con lo proyectado, lo soñado con lo vivido. El cinematógrafo invierte su mirada y proyecta la imagen sobre nosotros. Persona nos mira mientras la vemos para convertir al espectador en la pantalla que representa el sueño del autor.

\section{Máscara}

En la novela Niños del domingo, de marcado carácter autobiográfico, Bergman narra el tormento de su padre cuando descubre, en el ocaso de su vida, los diarios íntimos de su mujer ya fallecida. Descubrir esos diarios supone descubrir una verdad aterradora: «Leo y leo. Poco a poco me voy dando cuenta de que nunca conocí a la mujer con la que viví más de cincuenta años» (Bergman, 1994, 134). Pero hay más, al no conocer a su mujer tampoco se conoce a sí mismo. Las confesiones privadas de Karin revelan los verdaderos sentimientos hacia su marido: «Erik es intransigente. Erik nunca puede perdonar ni hace la vista gorda, por muy pastor que sea. Erik se conoce muy poco a sí mismo» (1994, 137). Una pregunta vuelve una y otra vez a su conciencia y no le deja descansar: «¿Qué es lo que he hecho mal?», repite insistentemente. Es entonces cuando su hijo Ingmar le da algunas claves para encontrar la respuesta, y, en este momento, como Ulises al escuchar su propia historia en boca de Demódoco², toma conciencia de su profundo desconocimiento.

1 André Gaudreault y François Jost recuerdan que el término es de Roger Odin y la expresión es, en su conjunto, herencia de Jean-Pierre Meunier, que se refiere más bien a la «actitud-documental» y a la «actitud-de-ficción» (Gaudreault A. y Jost, F., El relato cinematográfico, Barcelona, Paidós, 1995, p. 39)

2 En el Canto VIII de La Odisea de Homero, Ulises, ocultando las lágrimas de su rostro tras escuchar el episodio del caballo de Troya narrado por otro, revela su verdadera identidad ante los feacios mientras asume el relato de la historia. 
«Nosotros mismos somos desconocidos para nosotros mismos», escribió Nietzsche en el prólogo de La genealogía de la Moral (2005, 21), recordando así la imposibilidad de afrontar nuestra propia condición desde el interior, pues el conocimiento del yo se lleva a cabo desde una interpretación ajena, desde un tú que está detrás del espejo evadiendo la mirada. La reflexión que lleva a la autoconciencia provoca, en un instante de contemplación de la «infinita distancia» que nos separa del mundo, el surgimiento de la noción de persona unida a la máscara.

En este punto, la etimología puede ayudarnos a comprender el origen de una problemática todavía vigente. Así, pues, Persona, vocablo latino que significa «máscara de actor» o «personaje teatral», deriva del phersu etrusco ( $\varphi$ ersu), y éste, a su vez, del prósōpon griego $\left(\pi \rho \sigma^{\sigma} \sigma \omega \pi \mathrm{v}\right)$, cuyo origen etimológico alude a «lo que está delante del rostro». La herencia latina utilizaba el verbo per sonare (resonar) para designar a la máscara, puesto que estaban diseñadas para resonar con la voz del actor durante la escenificación de la tragedia y los rituales religiosos de la Grecia Antigua. De esta manera, además de elevar el volumen de la voz, se alteraba su percepción sonora para evitar el reconocimiento del actor, pues visualmente permanecía escondido tras una representación tipológica de las expresiones del rostro. La máscara, por tanto, desempeña una función de identificación con los caracteres o los dramatis personae representando un rostro, pero sin aludir a los rasgos y matices específicos de la individualidad. Esta ocultación de las cualidades estrictamente personales del actor le permiten ser una proyección arquetípica del personaje. Hans Belting afirma que «la máscara o el disfraz ocultan el cuerpo con el solo propósito de mostrar algo con él que él no podría mostrar por sí mismo, con lo que lo transforman en imagen» $(2007,118)$. Las más antiguas formas de drama y ritual han hecho uso de tales motivos en un intento de universalizar las particularidades del actor en el escenario. Pero el espectador de teatro es actor de la vida, y el refrán latino homo plures personas sustinet deja paso al popular pasaje shakesperiano pronunciado por Jaques en As you like it (1599): «El mundo entero es un escenario, y todos los hombres y mujeres, simplemente, comediantes». La máscara se convierte así en uno de los fundamentos de aquel theatrum mundi que se apodera de la cultura occidental durante la modernidad del siglo XVII. La metáfora barroca de El gran teatro del mundo llegaría a ser una de las claves fundamentales de la psicología analítica de Jung al recordar que «la persona es una mera apariencia» (2007, 245). Jung explica el vínculo entre la persona y la máscara desde la equivalencia conceptual de ambos términos, ya que el individuo «se pone una máscara, de la que sabe que corresponde, de un lado, a sus intenciones, y, de otro, a las exigencias y opiniones de su ambiente; [...]. A esa máscara, es decir, a la actitud adoptada ad hoc, yo la llamo persona» $(2013,758)$. Sin embargo, tras el sincretismo de la psique colectiva en la máscara se intuye una intimidad singular que promete convertir al hombre en individuo. Es lo que Jung denomina como ánima o alma, la mentira de un «carácter real» que prevalezca sobre las modificaciones adquiridas por el reflejo social $(2013,762)$. Y Alma es también aquello que Elisabet trata de hallar desesperadamente en las profundidades de su ser, pero no encuentra más que un silencio eterno, un reflejo en el espejo donde «se ve cómo su cara se transforma, se convierte en una máscara fría y voluptuosa a un tiempo» (Björkman, et al, 1973, 207). La movilidad impide la aprehensión de lo inmóvil que aparentemente subyace entre las manifestaciones expresivas del rostro. Se trata de una «sustancia indi- 
vidual concreta», una hipóstasis ${ }^{3}$ que, a su vez, guarda semejanzas significativas con el término griego charakter, equivalente a lo inmutable del individuo. Existe, por tanto, la presunción de un elemento constante a pesar de las modificaciones o accidentes externos sufridos por el transcurso del tiempo. Si bien David Napier asegura que «la convención del enmascaramiento ofrece una perspectiva de la conciliación de las ambigüedades del cambio» $(1986,15)$, E.H. Gombrich aborda esta cuestión desde la percepción fisonómica del rostro: «La sensación de constancia predomina de forma absoluta sobre el cambio de aspecto. [...]. Ningún crecimiento o decadencia alguna puede destruir la unidad del aspecto individual» $(1996,22)$. El movimiento del rostro, el flujo temporal sobre la piel, deja pruebas permanentes de lo que sucedió, rastros del pasado que parecen demostrar la existencia de una unidad inmóvil tras las constantes variaciones. No obstante, esta visión idealista alcanza su propio límite al reflexionar sobre la total correspondencia entre el temperamento interno y su manifestación externa. Este escepticismo bergmaniano es el fundamento de su retrato cinematográfico: la filmación de las «apariencias de la variación» sobre el espacio alegórico del rostro (Vázquez Couto, 2016), que pone en tela de juicio la "idea" de la tradición al dudar de la existencia de una sustancia invariable e indivisible: «La señora Vogler ansía la verdad. La ha buscado por todas partes y a veces ha creído encontrar algo sólido, algo duradero, pero de pronto el suelo ha cedido» (Bergman, 2007, 56). Algo volátil se esfuma ante la curiosa mirada del hombre, provocando la extrañeza de existir entre las ruinas de una identidad ficticia. Si hay una verdad discernible por el otro, está oculta entre las variaciones del rostro. Pero el rostro es para Bergman la imagen fantasmagórica creada por una linterna mágica, una ilusión efímera que llega a la negación de la persona como sustancia a partir de su reducción fenomenológica.

\section{Lenguaje}

«Nuestra relación con el habla es indeterminada, oscura, casi muda» (Heidegger, 1987, $18)^{4}$. Es este enigma oculto tras la palabra lo que impulsa a la actriz de teatro Elisabet Vogler a enmudecer durante su interpretación de Electra -súbitamente, un estado de dolorosa clarividencia invade la conciencia de Elisabet y revela la farsa que acompaña a cada palabra, cada acción, cada leve gesto expresado en el rostro-. Un estado, en definitiva, de expectación muda ante la cruel realidad del mundo: «Cuando la orientación consciente se derrumba [...] se trata de un pequeño fin del mundo, en el que todas las cosas retornan una vez más al caos de los comienzos» $(2007,254)$. Así lo definía Jung en 1928, como una vuelta a la entropía original tras la reflexión que provoca la pérdida del referente, del lenguaje, donde las ruinas del pasado no prometen un futuro. «La vida empieza a ser vivida en un doble plano» en

3 Eugenio Trías explica las tres hipóstasis (el intelecto, el alma y la naturaleza) que impulsan la metafísica moderna desde el presupuesto neoplatónico del Uno: «En el orden del Nous habría siempre dos términos, la inteligencia y la idea [...] Ambos términos presupondrían un "tercer término", el Uno (lo indiviso) [...] Inalcanzable por el intelecto, el Uno dejaría de ser "uno" al convertirse en objeto de entendimiento» (Trías, E., Lo bello y lo siniestro, Barcelona, Ariel, 1988, p. 49)

4 En las tres conferencias tituladas La esencia del habla que se celebraron en el Studium Generale de la Universidad de Freiburg im Breisgau los días 4 y 18 de diciembre de 1957 y el 7 de febrero de 1958, Heidegger busca «la posibilidad de hacer una experiencia con el habla» que «nos alcanzará en lo más interno de nuestra existencia» $(1987,142-143)$ 
un instante de plena conciencia -distensión temporal en la que el sujeto experimenta una «ausencia de hogar» (Trías, 1974: 79)-. Este sentimiento aparece como un relámpago en el sujeto consciente de la insuficiencia del lenguaje para llegar a satisfacer la necesidad comunicativa. La bifurcación de caminos que aparece ante la vista del explorador que busca la verdad, su verdad, obliga a una elección extrema:

O usamos un lenguaje inesencial y degradado, apto para fines del tráfico, un lenguaje convertido en 'vehículo de información', cuando no en 'valor de cambio', o bien nos sumimos en un impávido silencio, dejando el 'valor de uso' para un goce en soliloquio que nos aproxima al estado catatónico $(1974,73)$.

La comunicación se convierte así en un fraudulento proceso selectivo del intelecto que pervierte el mensaje e imposibilita la unión profunda con el otro, $\mathrm{y}$, en consecuencia, con uno mismo. Bergman no deja lugar a dudas sobre esta interpretación, pues él mismo lo admite con las palabras confesas del diario de Elisabet: «Me parecía que cada tono en mi voz, cada palabra en mi boca era mentira, un juego para ocultar vacío y hastío. Sólo había una manera de salvarse de la desesperación y del colapso. Callar. Descubrir la claridad detrás del silencio» (2007, 57). Ante las trampas impuestas por el lenguaje, Elisabet opta por el intento de abandonar la actuación manteniendo un silencio que se prolonga más allá de los escenarios. La señora Vogler pertenece a esa tipología de «hombre manierista» que «tenía demasiada conciencia respecto al carácter de farsa y de enmascaramiento de toda acción para poder hallar estímulos con vistas a ejecutarla» (Trías, 1974, 130). Elisabet es consciente de la distancia que la separa del mundo, de la falsedad que no logra evitar cuando intenta expresar la complejidad de su ser. No hay palabras para explicar lo que es en realidad, ni razonamiento capaz de alcanzarlo, pues el ser se encuentra en los límites de la razón que interrumpe el acto comunicativo con el mundo. Es el vacío de la significación.

Sobre el filo cortante del límite, la mentira teje la red de las relaciones humanas, puesto que la voz sincera duele al ser oída. Por este motivo sugiere Lloyd Michaels que «a la tiranía de mentiras, Bergman responde con la necesidad de ilusiones» $(2000,18)$. La acción y la palabra contienen un sentido oculto sujeto al escrutinio de la mirada externa. Alma, la ingenua enfermera que intenta ayudar a Elisabet, cree tener un vínculo especial con ella. Se siente dolida cuando descubre, al leer furtivamente las cartas de su paciente, los verdaderos pensamientos que se ocultan tras el silencio. Alma no reconoce lo que le resulta cercano y parece comprender que los actos se alejan cada vez más de los pensamientos. Poco después, Alma se asoma a través de una fina tela blanca que difumina sus facciones, pero el celuloide comienza a arder sobre su rostro y no deja más que una pantalla vacía (47’). La película interrumpe su narración para decirle al espectador que (el) Alma es imagen, que detrás de su máscara tan sólo hay una luz blanca.

Bergman apunta en sus diarios de trabajo una escena de la película que nunca llegó a realizar, pero a la que reconoce un valor relevante a la hora de describir la idea del film: «Cuando el novio de Alma, la enfermera, acude a visitarla, ella lo oye hablar por primera vez. Nota cómo la toca. Queda horrorizada porque se da cuenta de que está actuando, está interpretando un papel» $(2007,54)$. Es la caída de la máscara -el derrumbe de toda la estructura cultural protectora que deja al descubierto la impostura cotidiana- la que atrapa 
a su espectador entre los escombros que ha dejado la representación. Bergman convierte la condena del hombre a la soledad en una analogía del espacio existente entre las imágenes y los individuos. Un abismo entre el hombre y el mundo que la doctora de la clínica psiquiátrica (Margaretha Krook) expone claramente ante Elisabet:

¿Crees que no lo entiendo? El sueño imposible de ser. No de parecer, sino de ser. Consciente en cada momento. Vigilante. Al mismo tiempo, el abismo entre lo que eres para los otros y para ti misma, el sentimiento de vértigo y el deseo constante de, al menos, estar expuesta, de ser analizada, diseccionada, quizás incluso aniquilada. Cada palabra una mentira, cada gesto una falsedad, cada sonrisa una mueca. ¿Suicidarse? ¡Oh, no! Eso es horrible. Tú no harías eso. Pero puedes quedarte inmóvil y en silencio. Por lo menos así no mientes. Puedes encerrarte en ti misma, aislarte. Así no tendrás que desempeñar roles, ni poner caras ni falsos gestos. Piensas. Pero, ¿ves? La realidad es atravesada, tu escondite no es hermético. La vida secuela por todas partes. Estás obligada a reaccionar. Nadie pregunta si es real o irreal, si tú eres verdadera o falsa. La pregunta sólo importa en el teatro. Y casi ni siquiera allí. Te entiendo, Elisabet. Entiendo que estés en silencio, que estés inmóvil, que hayas situado esta falta de voluntad en un sistema fantástico. Te entiendo y te admiro. Creo que debes mantener este papel hasta que se agote, hasta que deje de ser interesante. Entonces podrás dejarlo. Igual que poco a poco fuiste dejando los demás papeles (18').

Se trata, por tanto, de la imposibilidad del ser, de un deseo inalcanzable de autenticidad que se diluye en la apariencia. El esfuerzo de hallar una verdad pacificadora resulta inútil, pues «todo espíritu profundo necesita una máscara: aún más, en torno a todo espíritu profundo va creciendo continuamente una máscara, gracias a la interpretación constantemente falsa» (Nietzsche, 2001, 70). Y también el silencio, como renuncia a la mediación del ser, es sólo otra máscara más de la identidad desconocida. El silencio de la angustia aparece ante la contemplación de un paisaje interno vacío, sin la unidad portadora de las múltiples máscaras. La nada al final del abismo, y, finalmente, la palabra «nada» es la que rompe el silencio de Elisabet (79').

\section{Memoria}

Un cineasta griego llamado A (Hervey Keitel), tras un largo exilio en Estados Unidos, regresa al hogar de su juventud en busca de las imágenes perdidas de la memoria. Es La mirada de Ulises (To Vlemma tou Odyssea, 1995), de Theo Angelopoulos, la que retorna sobre sí misma tratando de recuperar la identidad perdida en aquellas imágenes de los orígenes. Recuerdos que un día fueron parte del presente ahora se esconden entre la niebla blanquecina de un paisaje en guerra. Durante su odisea, A se encuentra con Ivo Levy (Erland Josephson), un arqueólogo de imágenes que conserva y protege el patrimonio fílmico de la destrucción de la guerra en Sarajevo: «Debía salvar nuestra memoria», le explica al álter ego de Angelopoulos (124'). Y no es casualidad que mencione Persona como uno de los films que han cambiado la historia del cine. Cambio que viene dado por esa mirada primeriza y pura del autor que anhela el Ulises moderno de Angelopoulos: «Ahora es una mirada que 
lucha por salir de la oscuridad. Como un nacimiento» (128'). Esta es la mirada de Persona, uno de los dramas culpables de la agonía del cine trágico que no se determina autoconsciente, que no se piensa como objeto de reflexión capaz de crear imágenes que forman parte de la experiencia del hombre. Al reflexionar sobre el valor existencial de las imágenes como parte integrada de la identidad, mezclándose con los recuerdos y deformando la memoria, se concede al film una vida propia como "persona" para conseguir el «retorno a la imagen» de la «modernidad melancólica» (Molinuevo, 2010). La última secuencia del La mirada de Ulises muestra la desolación de A contemplando la luz blanca y parpadeante de un proyector sin film sobre la pantalla de un cine en ruinas. La luz blanca es el silencio de la imagen, la sin imagen, una imagen sin lenguaje constituida por todas las longitudes de onda del espectro visible. En otras palabras, es una unidad múltiple que deja lugar para la alegoría en la memoria del melancólico que no sólo reproduce un pasado real imposible, sino también una identidad real imposible, como concluye A, finalmente, con lágrimas en los ojos: «Cuando regrese lo haré con las ropas de otro, con el nombre de otro. Nadie me esperará» (165').

Si bien A camina envuelto por el espesor de la niebla, los personajes de Persona «están insertos en la blancura» (Björkman, et al, 1973, 201), por lo que en el deseo de volver a empezar, de retornar a la juventud perdida que evite la nada de la desmemoria, se esconde una paradoja: la mirada diáfana que permite al sujeto contemplarse a sí mismo sólo es posible mediante la recuperación de un pasado acelajado. De este modo, la memoria acerca al hombre al precipicio del vacío original, pues sin memoria no somos, como ya había afirmado Wolff en 1734 al definir la persona como un «ente que conserva la memoria de sí, es decir, que se acuerda de que es aquello mismo que estuvo antes en este o aquel estado» (1972, 660). Sin embargo, volviendo al tema de la máscara, si admitimos la conceptualización del mundo como un gran teatro al estilo calderoniano, la interpretación que se prolonga durante toda la vida se renueva con el recuerdo de cada puesta en escena. La actuación convierte al actor en su personaje, una imagen creada por el recuerdo del público. Por eso Rosset considera a la identidad social (yo «identitario») como la única identidad real, y a la identidad personal (yo «pre-identitario») una mera ilusión sin posibilidad de existencia real: «Si bien el yo no puede más que encomendarse a su propia memoria, no puede tratarse más que de su memoria en cuento ser social» $(2007,27)$. El hombre, por tanto, es una representación de sí mismo que se construye con la memoria, es su propio recuerdo creado a partir de la experiencia social. Y puesto que no es posible el recuerdo sin experiencia, tampoco existe una identidad fuera de estos límites. Por este motivo la señora Vogler pretende deshacerse de las cadenas de la memoria rasgando la foto de su hijo, pues el pasado la retiene en una identidad social ligada a la condición de madre. Tras reflexionar, es decir, tras «volver sobre sí misma» y recuperar la mirada primeriza del niño que acaricia la imagen de un rostro asimétrico en la pantalla, descubre el drama de la sin identidad. Elisabet desea una especie de "grado cero" de sí misma, una vuelta a empezar que la permita creer en algo que no despierte la conciencia del vacío. Así concluye la impiedad bergmaniana, con el rostro compuesto del extrañamiento que devuelve la mirada a su espectador. Alma y Elisabet son reflejos de las imágenes de sí mismas, y el blanco, al fin y al cabo, el negativo de la oscuridad.

La memoria lleva hacia el silencio eterno del espejo que no deja lugar a la existencia fuera de su reflejo. Y, a partir de la escisión que abre un abismo ante la mirada, la autoconciencia del límite devuelve al hombre, como al cine, a sus orígenes, al silencio de la imagen. 
Bergman filma aquel drama moderno de la tradición clásica que se miraba a sí mismo, transformándolo en cine, en lenguaje de imágenes que cuestiona su propia lengua. Y si para Bergman la persona es imagen, su rostro es una máscara, por lo que en el «nihilismo del rostro ${ }^{5}$ ya defendido por Deleuze hay inherente un nihilismo de la imagen, una renuncia al idealismo platónico que no supo satisfacer la curiosidad del escéptico. Persona es, por tanto, la imagen cinematográfica, pero es también el espectador de la confusión entre el rostro y la máscara, porque si el hombre no es más que una sucesión de máscaras, el cine, como el mundo, no es más que una sucesión de imágenes. Es el drama de la identidad atrapada en la tragedia de la máscara; un drama, en definitiva, de la modernidad que contempla con mirada melancólica el recuerdo de su existencia.

\section{Bibliografía}

Belting, H. (2007), Antropología de la imagen, Madrid, Katz.

Bergman, I. (2007), Imágenes, Barcelona, Tusquets.

Bergman, I. (1994), Niños del domingo, Barcelona, Tusquets.

Björkman, S., Manns, T. y Sima, J. (1973), Conversaciones con Ingmar Bergman, Barcelona, Anagrama.

Gombrich, E. H. (1996), «La máscara y la cara: La percepción del parecido fisonómico en la vida y en el arte», en: E. H. Gombrich, J. Hochberg y M. Black., Arte, percepción y realidad, Barcelona, Paidós, pp. 15-17.

Heidegger, M. (1987), De camino al habla, Barcelona, Serbal, 1987.

Hubner, L. (2007), The Films of Ingmar Bergman: Illusions of Light and Darkness, New York, Palgrave Macmillan.

Jung, C. G. (2007), «Dos escritos sobre psicología analítica», en: Obra Completa, vol. 7, Madrid, Trotta.

Jung, C. G. (2013), «Tipos psicológicos», en: Obra completa, vol. 6, Madrid, Trotta.

Michaels, L. (2000), «Bergman and the Necessary Illusion: An introduction to Persona», en: L. Michaels (Ed.), Ingmar Bergman's Persona, Cambridge, Cambridge University Press, pp. 1-23.

Molinuevo, J. L. (2010), Retorno a la imagen. Estética del cine en la modernidad melancólica, Salamanca, Archipiélagos.

Napier, A. D. (1986), Masks, Transformation, and Paradox, Berkeley: University of California Press.

Nietzsche, F. (2001), Más allá del bien y del mal, Madrid, Alianza.

Nietzsche, F. (2005), La genealogía de la Moral, Madrid, Alianza.

Losilla, C. (2010), La invención de la modernidad. Historia y melancolía en el relato del cine, Tesis Doctoral, Universidad Pompeu Fabra.

Rosset, C. (2007), Lejos de mí, Barcelona, Marbot.

Trías, E. (1974), Drama e identidad (o bajo el signo de interrogación), Barral, Barcelona.

5 «Bergman llevó hasta su extremo el nihilismo del rostro, es decir, su relación en el miedo con el vacío o con la ausencia, el miedo del rostro frente a su nada» (Deleuze, G., La imagen-movimiento. Estudios sobre cine I, Barcelona, Paidós, 1984, p. 148) 
Trías, E. (2000), «Razón y religión en el fin del milenio», Revista catalana de teología, XXV, pp. 509-523.

Vázquez Couto, D. (2016), «Apariencias de la variación: fisonomía y alegoría en el retrato cinematográfico de Ingmar Bergman», FOTOCINEMA. Revista Científica de Cine y Fotografía, $\mathrm{n}^{\circ}$ 12, pp. 131-154.

Wolff, C. (1972), «Psycologia rationalis», en: J. École (Ed.), Christian Wolff's Gesammelte Werke II, Abeteilung, Band 6, Hildesheim, Olms. 